\title{
The effect of compensation and career development on lecturer job satisfaction
}

\author{
Angrian Permana ${ }^{a}$, M. Havidz Aima ${ }^{a}$, Eny Ariyanto ${ }^{a}$, Adi Nurmahdi ${ }^{a}$, Ahmad Hidayat Sutawidjaya ${ }^{a}$ \\ and Endri Endri ${ }^{a^{*}}$
}

${ }^{a}$ Universitas Mercu Buana, Jakarta, Indonesia

\section{H R O N I L E \\ A B S T R A C T}

\section{Article history:}

Received: January 1, 2021

Received in revised format:

April 32021

Accepted: April 4, 2021

Available online:

April 6, 2021

\section{Keywords:}

Compensation

Career Development

Job Satisfaction

\begin{abstract}
This study aims to determine the effect of compensation on job satisfaction, career development on job satisfaction, and the effect of compensation and career development together on lecturer job satisfaction at private universities. This research uses quantitative methods with a total sample of 98 people spread across private universities in Serang City with B and C accreditation. The analytical tool used in this study uses multiple regression with the SPSS version 24 tool. The results of this study are compensation influences on lecturer job satisfaction, career development influences on lecturer job satisfaction, and compensation and career development together influence lecturer job satisfaction.
\end{abstract}

C 2021 by the authors; licensee Growing Science, Canada

\section{Introduction}

Education is an important factor for human needs. Developed countries can be seen from the economic side which is extraordinarily supported by their education (Sahlberg, 2010). Therefore, education cannot be ignored and underestimated by the government and society as a very vital factor (Silitonga et al., 2020). According to Hanushek and Rivkin (2006), the role of teaching staff in building education is very important, qualified teaching staff will transmit intelligences to their students. Likewise, with the role of lecturers as teaching staff who must have quality in implementation. Mediawati (2010) stated that confident in the transfer of knowledge that can be seen from the increasing knowledge, changes in attitudes and behavior of her students. Serang is one of the capital cities of a province, namely Banten province. The city with the slogan Serang Bertaqwa has various types of education, one of which is higher education. Higher education which consists of Colleges, Universities, Polytechnics, and Academics is in this city. Various students from different circles come from other cities to achieve their dreams, ranging from students who were working and not working. Higher education institutions in Serang City do not yet have a number of qualified campuses, of the 400 best private universities according to SINTA, there is only one private university that enters, namely Serang Raya University with the 295th rank. According to Webometrics there is not a single private university in the top 400, and according to 4CIU.ORG there is only one private university that is included in the best 400 private universities, namely Banten Jaya University, with the 269th rank. In addition, private universities in Serang City have not been accredited A and only a few have B and C accreditations, while the rest are not yet accredited. According to Prof. Dr. Uman Suherman, M.Pd, quoted in Pikiran-rakyat.com, in order for higher education institutions to achieve A accreditation or predicate of excellence, more of their study programs must be accredited A. In addition, the qualifications and academic positions of lecturers play a role very important. He said that excellent study programs can only be achieved on campus with campuses that

* Corresponding author. Tel.: +628129204067

E-mail address: endri@mercubuana.ac.id (E. Endri) 
have lecturers with good qualifications and academic positions. The city of Serang only has six campuses with accreditation colleges B and C. Accreditation B is owned by the Serang Raya University campus, Banten Jaya University, and the Bakti Purna Husada Midwifery Academic College Meanwhile, the $\mathrm{C}$ accreditation is owned by STIA Maulana Yusuf, STKIP Pelita Pratama, and Polytechnic of Input Serang. In addition, there are still those registered and not accredited.

To maintain the quality of higher education, meeting the needs of teaching staff (lecturers) is one factor that cannot be ignored. Compensation is an important factor, which is based on several previous studies conducted by Nawab and Bhatti (2011), Islam et al. (2012), Sundari et al. (2020) and Parimita et al. (2018), which explain that with sufficient compensation, lecturer satisfaction will run well. If satisfaction is established in an organization, loyalty in that organization will increase (Eyupoglu et al., 2017). Apart from the compensation factor, the role of career development is also quite an important factor with a career development faced by lecturers the lecturer can be more loyal to certain universities. Career development for lecturers is quite important because with a future career, they will have enthusiasm in implementing the tri dharma of higher education (Zacher et al., 2019). Feelings of pleasure and happiness can be felt by someone by getting a certain satisfaction. If satisfaction is obtained from within, of course there are factors that cause satisfaction. The lecturer satisfaction factor may be influenced by the compensation and career development received by private universities in Serang City, where based on the survey results, compensation and career development for lecturers in Serang City are still low.

\section{Literature review}

\subsection{Compensation}

Compensation is an element of work relations that often causes problems in industrial relations. Compensation issues have always been a concern of organizational management, employees, and the government, especially wages (Sundari et al., 2020). Management takes wages into account because they are a major part of production and operating costs, defines the performance of employees that must be paid, and affects their ability to recruit workers of a certain quality. There are several objectives of compensation, including: (a) getting a qualified personal; (b) retain existing employees; (c) shows fairness, both internal equity and external equity; (d) give rewards for behavior that is appropriate to the organization; (e) control funds; (f) adjust to existing wage regulations; (g) motivate employees; and (h) reduce employee Labor Turnover (Parimita et al., 2018). Compensation consists of financial and non-financial compensation. Financial compensation consists of indicators including salary, incentives, protection, deferred payments, compensation outside working hours, and facilities (Vizano et al., 2020). Meanwhile, the nonfinancial dimension consists of promotion, recognition, praise, job comfort, and colleagues (Setiyani et al., 2020)

\subsection{Career Development}

The development has a broader scope in an effort to improve and increase knowledge, abilities, attitudes and personality traits to assume different or higher responsibilities within the organization (Kim, 2018). The development of Human Resources (HR) is an activity that must be carried out by companies so that their knowledge, abilities and skills are in accordance with the demands of the work they are doing (Dahl et al., 2013; Susanto et al., 2020). The existence of development activities, employees are expected to be able to improve and overcome deficiencies in carrying out their work better, in accordance with the development of science and technology used by the company. to assume different or higher responsibilities within the organization (Mudor, 2011; Hapsari et al., 2021). According to Wang and Wanberg (2017), career development consists of two dimensions, namely, career management and career planning. Career management includes indicators of organizational policies, work performance, educational level, and regeneration. Meanwhile, career planning includes indicators of training, work experience, work relations, and self-development.

\subsection{Job Satisfaction}

Job satisfaction does not mean how hard or how well someone works, but how much people like the job. This assessment can be made of one of the important values in work. Satisfied employees prefer their work situation rather than dislike them, so it can be stated that job satisfaction is the result of fulfilling several wants and needs through work activities (Abubakar et al., 2014). Job satisfaction theory is supported by several studies published in the journal states that job satisfaction is caused by many factors, one of which is about payment (Sundari et al., 2020), consists of extrinsic and intrinsic factors and has a strong relationship with leadership (Wang \& Wanberg, 2017). In addition, lecturer job satisfaction is caused by leadership and organizational culture (Zacher et al., 2019). The factors that cause job satisfaction consist of the job itself, salary, supervision, promotion opportunities, and relationships with colleagues (Supriyanto, 2013). Job satisfaction consists of three dimensions, namely, (1) individual factors including age, health, character, and expectations, (2) social factors consisting of kinship, community views, creative opportunities, union activities workers, political freedom, and social relations, (3) the main factors 
in work which consist of wages, supervision, job security, working conditions, and opportunities to advance (Bayarçelik \& Findikli, 2016).

\section{Methods}

The location of this research is located in the city of Serang. The population is lecturers who serve in private universities (PTS) with accreditation for campuses B and C, namely Serang Raya University, Banten Jaya University, Maulana Yusuf College of Administration (STIA) Maulana Yusuf, Pelita Pratama Teacher Training and Education College (STKIP), and PIKSI INPUT Polytechnic. The population in this study was probably 236. The sample was taken using the Slovin formula with an error rate of 5\% with a total sample size of 148 respondents. Of the questionnaires distributed as many as 148,103 of which returned and as many as 98 questionnaires can be entered, as many as 5 respondents were filled incompletely. So that the data can be counted as many as 98 . This study uses quantitative methods with multiple analysis tools. The tool used is SPSS version 2.4 . The scale used is a five-point Likert scale. The independent variable in this study is compensation (X1) and career development (X2), while the dependent variable is job satisfaction (Y).

\section{Table 1}

Dimensions Variable and Indicator

\begin{tabular}{|c|c|c|c|}
\hline No. & Conceptual Definition & Dimensions & Indicator \\
\hline 1. & $\begin{array}{l}\text { Compensation: All income in the form of money, } \\
\text { direct or indirect goods received by employees in } \\
\text { return for services rendered to the company (Zainal } \\
\text { et al. 2015) }\end{array}$ & $\begin{array}{l}\text { Financial } \\
\text { Non } \\
\text { financial }\end{array}$ & $\begin{array}{l}\text { a. Salary } \\
\text { b. Incentive } \\
\text { c. Protection } \\
\text { d. Pending payments } \\
\text { e. Off-hours compensation } \\
\text { f. Amenities } \\
\text { a. Promotion } \\
\text { b. Recognition } \\
\text { c. Praise } \\
\text { d. Convenience of duty } \\
\text { e. Co-workers }\end{array}$ \\
\hline 2. & $\begin{array}{l}\text { Career development: efforts to change or enhance } \\
\text { an employee's career from another position in a } \\
\text { different space and class (Simamora, 2015) }\end{array}$ & $\begin{array}{l}\text { Career management } \\
\text { Career planning }\end{array}$ & $\begin{array}{l}\text { a. Organizational policies } \\
\text { b. Work performance } \\
\text { c. Level of education } \\
\text { d. Regeneration } \\
\text { a. Training } \\
\text { b. Work experience } \\
\text { c. Work relations } \\
\text { d. Self-development }\end{array}$ \\
\hline 3. & $\begin{array}{l}\text { Job Satisfaction: a positive feeling about someone's } \\
\text { job that is the result of an evaluation of their } \\
\text { characteristics (Blum in Sinambela, 2017) }\end{array}$ & $\begin{array}{l}\text { Individual factors } \\
\text { Social factors } \\
\text { The main factor in work }\end{array}$ & $\begin{array}{l}\text { a. Age } \\
\text { b. Health } \\
\text { c. Character } \\
\text { d. Hope } \\
\text { a. Family relation } \\
\text { b. Public views } \\
\text { c. Creative opportunities } \\
\text { d. Trade union activities } \\
\text { e. Political freedom } \\
\text { f. Community relations } \\
\text { a. Wage } \\
\text { b. Supervision } \\
\text { c. Peace of work } \\
\text { d. Working conditions } \\
\text { e. Opportunity for advancement }\end{array}$ \\
\hline
\end{tabular}

\section{Results and discussion}

The research questionnaire was tested using SPSS, and the results showed that all questionnaires were said to be valid and reliable. The results are valid because the value of $r$ count $>r$ table. The results of the validity test can be seen in Table 2 . For the reliability test, if the alpha value is $>0.90$ it is said to be perfect reliability, if the alpha is between $0.70-0.90$ then it is called high reliability. If the alpha is $0.50-0.70$ it is called moderate, and if the alpha value is $<0.50$ then the reliability is low. The test results show that the alpha value of the entire questionnaire is $>0.90$, this indicates that it is included in the perfect reliability category. 
Table 2

The results of this study indicate that all questionnaires are valid and reliable

\begin{tabular}{|c|c|c|c|c|}
\hline Variable & Indicator & r-value & Significance & Remarks \\
\hline \multirow[t]{11}{*}{ Compensation } & $\mathrm{X} 1$ & $.824^{* *}$ & .000 & Valid \\
\hline & $\mathrm{X} 2$ & $.806^{* *}$ & .000 & Valid \\
\hline & $\mathrm{X} 3$ & $.754^{* *}$ & .000 & Valid \\
\hline & $\mathrm{X} 4$ & $.833^{* *}$ & .000 & Valid \\
\hline & $\mathrm{X} 5$ & $.831^{* *}$ & .000 & Valid \\
\hline & X6 & $.787^{* *}$ & .000 & Valid \\
\hline & $\mathrm{X7}$ & $.815^{* *}$ & .000 & Valid \\
\hline & $\mathrm{X} 8$ & $.765^{* *}$ & .000 & Valid \\
\hline & X9 & $.780^{* *}$ & .000 & Valid \\
\hline & $\mathrm{X} 10$ & $.804^{* *}$ & .000 & Valid \\
\hline & $\mathrm{X} 11$ & $.798^{* *}$ & .000 & Valid \\
\hline \multirow[t]{8}{*}{ Career development } & $\mathrm{X} 12$ & $.860^{* *}$ & .000 & Valid \\
\hline & $\mathrm{X} 13$ & $.865^{* *}$ & .000 & Valid \\
\hline & $\mathrm{X} 14$ & $.853^{* *}$ & .000 & Valid \\
\hline & $\mathrm{X} 15$ & $.849^{* *}$ & .000 & Valid \\
\hline & X16 & $.855^{* *}$ & .000 & Valid \\
\hline & $\mathrm{X} 17$ & $.868^{* *}$ & .000 & Valid \\
\hline & $\mathrm{X} 18$ & $.869^{* *}$ & .000 & Valid \\
\hline & X19 & $.819^{* *}$ & .000 & Valid \\
\hline \multirow[t]{15}{*}{ Job satisfaction } & $\mathrm{X} 20$ & $.800^{* *}$ & .000 & Valid \\
\hline & $\mathrm{X} 21$ & $.718^{* *}$ & .000 & Valid \\
\hline & $\mathrm{X} 22$ & $.774^{* *}$ & .000 & Valid \\
\hline & $\mathrm{X} 23$ & $.837^{* *}$ & .000 & Valid \\
\hline & $\mathrm{X} 24$ & $.804^{* *}$ & .000 & Valid \\
\hline & $\mathrm{X} 25$ & $.820^{* *}$ & .000 & Valid \\
\hline & $\mathrm{X} 26$ & $.825^{* *}$ & .000 & Valid \\
\hline & $\mathrm{X} 27$ & $.850^{* *}$ & .000 & Valid \\
\hline & $\mathrm{X} 28$ & $.853^{* *}$ & .000 & Valid \\
\hline & X29 & $.820^{* *}$ & .000 & Valid \\
\hline & $\mathrm{X} 30$ & $.721^{* *}$ & .000 & Valid \\
\hline & X31 & $.783^{* *}$ & .000 & Valid \\
\hline & $\mathrm{X} 32$ & $.814^{* *}$ & .000 & Valid \\
\hline & X33 & $.807^{* *}$ & .000 & Valid \\
\hline & X34 & $.705^{* *}$ & .000 & Valid \\
\hline
\end{tabular}

Source: SPSS Data Processing, 2020

Table 3

Reliability test results

\begin{tabular}{clcc}
\hline No & \multicolumn{1}{c}{ Latent Variable } & Cronbach's Alpha & Remarks \\
\hline 1 & Compensation & .943 & Reliable \\
2 & Career development & .947 & Reliable \\
3 & Job satisfaction & .958 & Reliable \\
\hline
\end{tabular}

Source: SPSS Data Processing, 2020

The influence between independent variables (compensation and career development) on the dependent variable (job satisfaction) of lecturers in the private higher education environment of Serang City can be seen from the results of $t$ count between variables and the value of $r$ square. The results of the $t$ test and the square value of this study can be seen in Table 4 .

Table 4

Results of $t$ test and significance value

\begin{tabular}{|c|c|c|c|c|c|}
\hline \multirow[t]{2}{*}{ Model } & \multicolumn{2}{|c|}{ Unstandardized Coefficients } & \multirow{2}{*}{$\begin{array}{c}\text { Standardized } \\
\text { Coefficients } \\
\text { Beta }\end{array}$} & \multirow[t]{2}{*}{$\mathrm{T}$} & \multirow[t]{2}{*}{ Sig. } \\
\hline & $\mathrm{B}$ & Std. Error & & & \\
\hline (Constant) & 11.575 & 4.744 & & 2.440 & .017 \\
\hline Compensation & 1.239 & 2.162 & .182 & 3.010 & .002 \\
\hline Career Development & 1.186 & .230 & .635 & 5.154 & .000 \\
\hline
\end{tabular}

Based on the data obtained, it is known that the $t$ count variable $t$-count the compensation variable $>t$ table value, namely $3.010>$ 1.985 , these results indicate that compensation affects the job satisfaction of lecturers at private universities in Serang City. While the $\mathrm{t}$ value of the career development variable $>\mathrm{t}$ table, namely $5.154>1.985$ which indicates that there is a strong 
influence of career development variables on the variable job satisfaction of lecturers in private universities in Serang City. The $\mathrm{R}$ square value is 0.636 or $63.6 \%$, which means that the percentage of the contribution of the influence of the independent variable on the dependent variable is $63.6 \%$.

The $\mathrm{F}$ test in a study functions to determine the effect of the independent variables together on the dependent variable.

Table 5

The results of $\mathrm{F}$ test

\begin{tabular}{llccccc}
\hline Model & & Sum of Squares & Df & Mean Square & F & Sig. \\
\hline \multirow{2}{*}{1} & Regression & 16358.509 & 2 & 8179.255 & 83.133 & $.000^{\mathrm{a}}$ \\
& Residual & 9346.838 & 95 & 98.388 & & \\
\cline { 2 - 7 } & Total & 25705.347 & 97 & & & \\
\hline
\end{tabular}

a. Predictors: (Constant), Career Development, Compensation

b. Dependent Variable: Satisfaction

Based on the results of the $\mathrm{F}$ test data processing, it can be concluded that the value of the $\mathrm{F}$ test means that there is a joint influence of compensation and career development variables on lecturer job satisfaction. from these results explain that the hypothesis in this study is accepted. In addition to the F test, to determine the relationship between dimensions of each variable, a correlation calculation between dimensions was made. The correlation between dimensions can be seen in Table 6 .

Table 6

Inter-Dimensional Correlation

\begin{tabular}{llccc}
\hline & & Y1.1 & Y1.2 & Y1.3 \\
\hline $\mathbf{X 1 . 1}$ & Financial & $.684^{* *}$ & $.681^{* *}$ & $.711^{* *}$ \\
$\mathbf{X 1 . 2}$ & Non financial & $.637^{* *}$ & $.657^{* *}$ & $.679^{* *}$ \\
$\mathbf{X} 2.1$ & Career management & $.760^{* *}$ & $.763^{* *}$ &. $\mathbf{7 9 2}^{* *}$ \\
$\mathbf{X 2 . 2}$ & Career planning & $.681^{* *}$ & $.695^{* *}$ & $.716^{* *}$ \\
\hline Y1.1 & Individual factors & 1 & $.892^{* *}$ & $.940^{* *}$ \\
$\mathbf{Y 1 . 2}$ & Social factors & $.892^{* *}$ & 1 & $.986^{* *}$ \\
Y1.3 & The main factor at work & $.940^{* *}$ & $.986^{* *}$ & 1 \\
\hline
\end{tabular}

Source: Primary data processed (2020)

Based on the results of data processing, it can be seen that each variable between dimensions has a strong enough relationship. Table 4 shows that the correlation between the financial dimensions has the strongest relationship with the main factor dimensions at work, and the career planning dimension has the strongest relationship with the same dimension, namely the main factors at work.

\section{Conclusion}

Based on the results of data processing, researchers can provide conclusions in this study, including:

1. Compensation has an influence with the job satisfaction variable, it can be seen that the $\mathrm{t}$ value is greater than the $\mathrm{t}$ table, and the significant value is less than 0.005 . The most influential dimension in the inter-dimensional correlation test is the financial dimension with the main factor at work, which has a correlation value of 0.711 . Based on these results, it can be suggested that to increase the job satisfaction of lecturers, more financial compensation needs to be given. Therefore, special attention is needed for lecturers in financial compensation.

2. Career development has an influence with job satisfaction variables, it can be seen that the $t$ value is greater than the $t$ table and the significant value is less than 0.005 . The most influential dimension of the career development variable in the inter-dimensional correlation process is career management with the main factor satisfaction dimension at work with a correlation value of 0.792 . Based on these results, it can be given that the dimensions of career management need to be taken into account and considered for lecturers in the city of Serang to increase the satisfaction of lecturers in their work.

3. Based on the results of the F test, it is known that the value of compensation and career development has a joint influence on job satisfaction with the $F$ test value of 83.133 is greater than $F$ table 3.09 , and a significance value of 0.000 . From the results of the $\mathrm{F}$ test, it can be suggested that compensation and career development are factors that need to be considered by every private higher education manager in Serang City to increase lecturer satisfaction at work.

\section{References}

Abubakar, R.A., Chauhan, A., \& Kura, K.M. (2014). Relationship between perceived organizational politics, organizational trust, human resource management practices and turnover intention among Nigerian nurses. Management Science Letters, 
4(9), 2031-2048.

Bayarçelik, E.B., \& Findikli, M.A. (2016). The Mediating Effect of Job Satisfaction on the Relation Between Organizational Justice Perception and Intention to Leave. Procedia - Society of Behaviour Science, 235, 403-411.

Dahl, S., Eagle, L., \& Ebrahimjee, M. (2013). Golden Moves. Social Marketing Quarterly, 19(4), $230-241$.

Eyupoglu, S.Z., Jabbarova, K., \& Saner, T. (2017). Job satisfaction: An evaluation using a fuzzy approach. Procedia Computer Science, 120, 691-698.

Hanushek, E. A., \& Rivkin, S. G. (2006). Teacher quality. Handbook of the Economics of Education, 2, $1051-1078$.

Hapsari, D., Riyanto, S. \& Endri, E. (2021). The Role of Transformational Leadership in Building Organizational Citizenship: The Civil Servants of Indonesia. Journal of Asian Finance, Economics, and Business, 8(2), 595-604. https://doi.org/10.13106/jafeb.2021.vol8.no2.0595

Islam, T., Ahmad, Z., Ahmed, I., Ahmad, A., Saeed, M., \& Muhammad, S. K. (2012). Does compensation and demographical variable influence on teachers commitment and job satisfaction? a study of university of the Punjab, Pakistan. International Journal of Business and Management, 7(4), 35-43

Kim, B. (2018). Effect of Psychological Empowerment on Turnover Intention through Job Satisfaction and Organizational Commitment: focus on Korea, China, Japan Employees. East Asian Journal of Business Economics, 6(2),1-13.

Mediawati, E. (2010). Pengaruh motivasi belajar mahasiswa dan kompetensi dosen terhadap prestasi belajar. Dinamika Pendidikan, 5(2), 134-146.

Mudor, H. (2011). Conceptual framework on the relationship between human resource management practices, job satisfaction, and turnover. Journal of Economics and Behavioral Studies, 2(2), 41-49.

Nawab, S., \& Bhatti, K. K. (2011). Influence of employee compensation on organizational commitment and job satisfaction: A case study of educational sector of Pakistan. International Journal of Business and Social Science, 2(8), 25-32

Parimita, W., Khoiriyah, S., Handaru, A.W. (2018). The Effect of Work Motivation and Compensation on Employee Job Satisfaction at PT Tridaya Eramin Bahari. JRMSI - J Ris Manaj Sains Indones. 9(1),125-144.

Sahlberg, P. (2010). The secret to Finland's success: Educating teachers. Stanford Center for Opportunity Policy in Education, 2, 1-8.

Setiyani, A., Sutawijaya, A., Nawangsari, L.C., Riyanto, S., \& Endri, E. (2020). Motivation and the Millennial Generation. International Journal of Innovation, Creativity and Change, 13(6),1124-1136

Silitonga, T.B., Sujanto, B., Luddin, M. R., \& Susita, D., \& Endri, E. (2020). Evaluation of Overseas Field Study Program at the Indonesia Defense University. International Journal of Innovation, Creativity and Change, 12(10), 554-573.

Sundari, E., Harini, S., \& Yuningsih, E. (2020). Compensation, Performance and Effect on Turnover Intention Home Delivery Personnel. Indonesian Journal of Social Resources. 1(2), 37-49.

Supriyanto, A.S. (2013). Role of Procedural Justice, Organizational Commitment and Job Satisfaction on job Performance: The Mediating Effects of Organizational Citizenship Behavior. International Journal of Business Management, 8(15), 57-68

Susanto, Y., Nuraini., Sutanta., Gunadi., Basrie., Mulyadi., \& Endri, E. (2020). The Effect of Task Complexity, Independence and Competence on the Quality of Audit Results with Auditor Integrity as a Moderating Variable. International Journal of Innovation, Creativity and Change, 12(12), 742-755.

Vizano, N. A., Sutawidjaya, A.A., \& Endri, E. (2021). The Effect of Compensation and Career on Turnover Intention: Evidence from Indonesia. Journal of Asian Finance, Economics, and Business, 8(1), 471-478.

Wang, M., \& Wanberg, C.R. (2017). 100 years of applied psychology research on individual careers: From career management to retirement. Journal of Appl Psychol. 102(3):546-563.

Zacher, H., Rudolph, C.W., Todorovic. T., \& Ammann, D. (2019). Academic career development: A review and research agenda. Journal of Vocational Behavior, 110,357-373

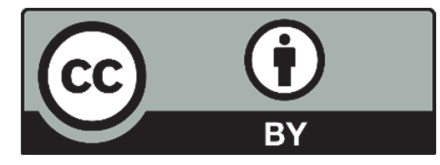

(C) 2021 by the authors; licensee Growing Science, Canada. This is an open access article distributed under the terms and conditions of the Creative Commons Attribution (CC-BY) license (http://creativecommons.org/licenses/by/4.0/). 